\title{
Contact lens-associated microbial keratitis
}

\author{
Ceratites microbianas relacionadas a lente de contato
}

\author{
Aline Silveira Moriyama ${ }^{1}$ \\ Ana Luisa Hofling-Lima ${ }^{2}$
}

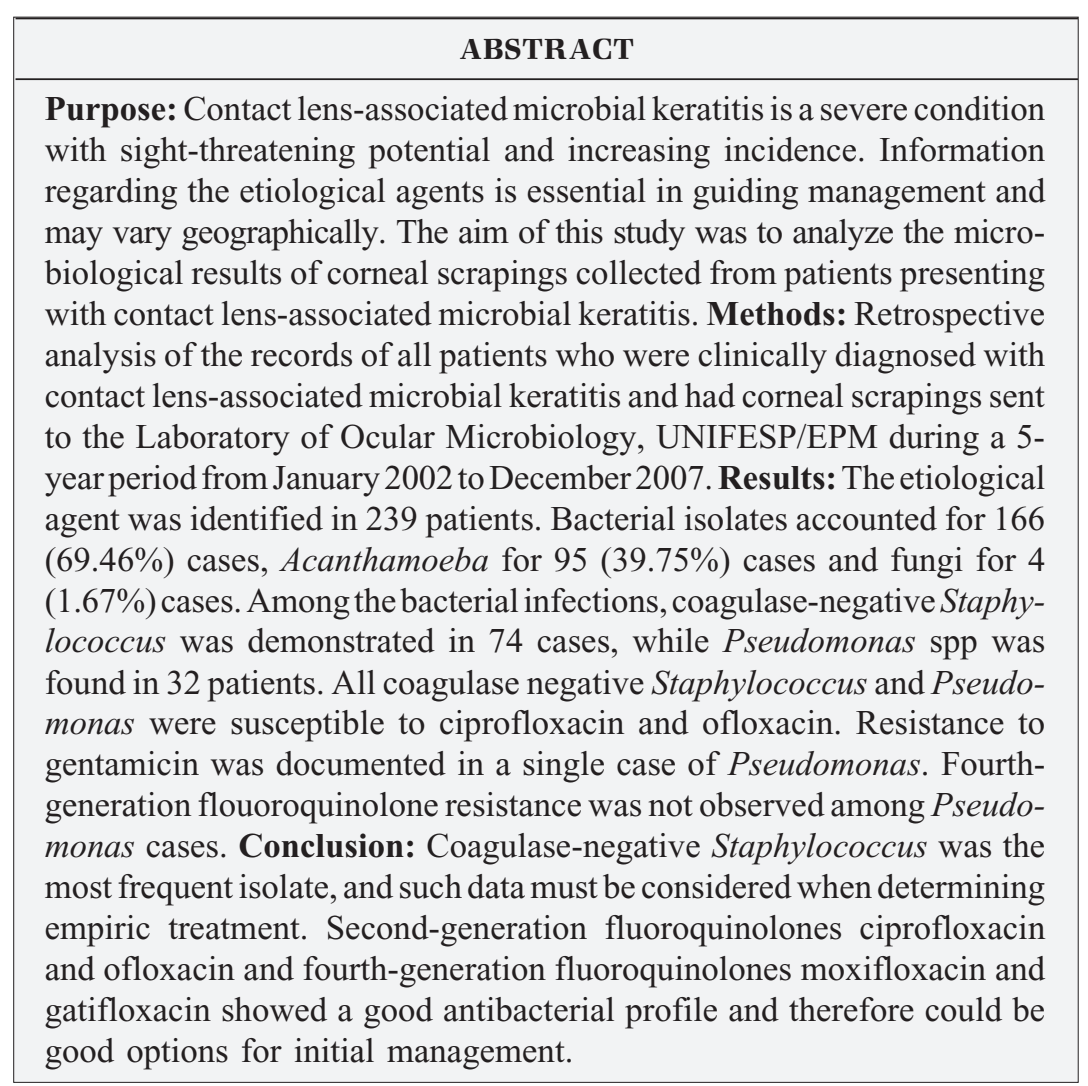

Keywords: Contact lens/adverse effects; Keratitis/microbiology; Eye infections, bacterial; Corneal ulcer; Acanthamoeba
Trabalho realizado no Departamento de Oftalmologia da Universidade Federal de São Paulo - UNIFESP - São Paulo (SP) - Brasil.

${ }^{1}$ Resident of Department of Ophthalmology of "Universidade Federal de São Paulo" - UNIFESP - São Paulo (SP) - Brazil.

${ }^{2}$ Chair of Department of Ophthalmology - UNIFESP - São Paulo (SP) - Brazil.

Address for correspondence: Aline Silveira Moriyama. Departamento de Oftalmologia, Universidade Federal de São Paulo - Rua Botucatu, 820 - São Paulo (SP) CEP 04023-062

E-mail: aline_moriyama@yahoo.com

\section{INTRODUCTION}

The use of contact lenses (CL) has been widely associated with corneal alterations ranging in symptomatology and severity. Lesions may vary from small peripheral sterile infiltrates to infectious central ulcers with sight-threatening potential ${ }^{(1-2)}$. Contact lens wear has been repeatedly described as the most important predisposing factor to microbial keratitis worldwide $^{(3-4)}$, including Brazil ${ }^{(5)}$. The incidence of microbial keratitis has increased over the past decades accompanying a growing population of CL wearers ${ }^{(6)}$. The incidence of CL-associated microbial keratitis (CLMK) varies from 1.8 to 2.44 per $10,000 \mathrm{CL}$ wearers/year ${ }^{(7)}$. Infections are more frequent in soft-lens users and the risk with gas-permeable rigid lenses is estimated to be one-third that with daily-wear soft lenses ${ }^{(8)}$. Extended wear is also associated with higher risk of microbial keratitis ${ }^{(9-11)}$, while the impact of frequent replacement in reducing or increasing the incidence of infectious keratitis is still unclear ${ }^{(11-12)}$. 
Most often, CLMK is related to bacterial infection, although Acanthamoeba and less frequently fungi can also be involved in the pathological process ${ }^{(6-7,13-14)}$. Bacterial keratitis is most commonly caused by aggressive gram-negative Pseudomonas spp. The bacterial agent seems to vary geographically according to climate and/or temperature. Temperate zones tend to have higher incidences of gram-positive and less aggressive keratitis ${ }^{(15)}$.

Amebic keratitis is a protozoal infection known to represent a severe condition with dramatic visual outcomes ${ }^{(16-17)}$ and to require a long and costly treatment ${ }^{(18)}$. The main risk factors for Acanthamoeba keratitis include failure to disinfect soft lenses, use of tap water to clean the lenses and the use of lenses while swimming ${ }^{(7,19-20)}$. Recently, confocal microscopy has been shown to be a valuable diagnostic tool, which could be especially helpful in cases with negative microbiological results despite clinical suspicion ${ }^{(21)}$.

Fungal infection was historically considered a rare form of CLMK and mostly associated with therapeutic $\mathrm{CL}^{(22)}$, though some developing countries may have higher rates even among non-therapeutic contact-lens wearers ${ }^{(23-24)}$. Recent reports of Fusarium keratitis outbreaks among nontherapeutic CL users ${ }^{(25-26)}$, although partially attributed to a specific multipurpose solution, point to CL use as a growing risk factor for fungal keratitis ${ }^{(27)}$.

The familiarity with the usual causative agents may help with the primary therapeutic choice. Several studies report the most frequent microbes involved in CLMK worldwide, but little data regarding the situation in Brazil is available. Considering the possible differences in CLMK agents according to regions and climate ${ }^{(15)}$, it is essential to gain knowledge of the most frequent agents of CLMK in our country.

The aim of our study was to analyze epidemiological data and microbiological results of all corneal scrapings collected from patients who were clinically diagnosed with CLMK during the period between January 2002 and December 2007 at the Laboratory of Ocular Microbiology, UNIFESP/EPM.

\section{METHODS}

We analyzed retrospectively the records of all patients who were clinically diagnosed with CLMK and had corneal scrapings sent to the Laboratory of Ocular Microbiology, UNIFESP/EPM during the 5-year period of January 2002 to December 2007. The following data were collected: gender, age, type of lens used (soft or hard), microbiological results including microscopic analysis and culture growth in different media of the corneal scrapings and also CL culture. All the scrapings were performed according to the standard routine of the Laboratory of Ocular Microbiology-UNIFESP/ EPM. Scrapings were always performed by a trained physician using slit lamp, Kimura scalpel, and topical anesthesia. Corneal material was smeared on 2 slides and stained with Giemsa and Gram stains. Corneal material was also added to thioglycollate (Thio) broth, brain-heart-infusion (BHI) broth, Sabouraud glucose agar plate, blood agar plate and chocolate agar plate, to test for microbial growth. Additional slide staining and/or culture media were used depending on the clinical suspicion. Non-nutrient agar with an overlay of Escherichia coli media, for example, was always used when Acanthamoeba infection was clinically suspected. On the other hand, fewer media and/or slides were used if only little material could be obtained.

\section{RESULTS}

During the period of January 2002 to December 2007, 2455 corneal scrapings were analyzed at the Laboratory of Ocular Microbiology, UNIFESP/EPM with the clinical diagnosis of infectious keratitis. Three hundred sixty-six (14.91\%) patients were CL users and among them, 239 had culture-proven microbial keratitis and were included in the study.

Mean age was 29.75 years (ranging from 9 to 84 years) and the male to female ratio was 1:1.26.

Bacterial agent accounted for 166 cases $(69.46 \%)$, while Acanthamoeba was verified in 95 patients $(39.75 \%)$ and fungus was isolated in 4 cultures $(1.67 \%)$. The causative organisms are shown in Table 1.

\begin{tabular}{|lc|}
\hline \multicolumn{2}{|c|}{$\begin{array}{c}\text { Table 1. Causative agents in culture-proven cases of contact } \\
\text { lens-related microbial keratitis }\end{array}$} \\
Microbiological agent & $\mathbf{n}$ \\
Gram-positive bacteria & $\mathbf{( 4 1 . 2 0 \% )}$ \\
Coagulase-negative Staphylococcus & 74 \\
Corynebacterium spp & 20 \\
Staphylococcus aureus & 10 \\
Streptococcus spp & 4 \\
Other gram-positive bacteria & 2 \\
Gram-negative bacteria & $\mathbf{2 1 . 7 2 \% )}$ \\
Pseudomonas spp & 32 \\
Pseudomonas aeruginosa & 13 \\
Pseudomonas fluorescens & 4 \\
Serratia spp & 15 \\
Enterobacter aerogenes & 5 \\
Klebisiella spp & 1 \\
Proteus mirabilis & 1 \\
Citrobacter freundii & 1 \\
Achromobacter xyloxidans & 1 \\
Alcaligenes spp & 1 \\
Moraxella spp & $\mathbf{1 1}$ \\
Acanthamoeba & $\mathbf{2 6 7}$ \\
Fungus & $\mathbf{1 0 0 \% )}$ \\
Candida spp & $\mathbf{( 1 . 5 0 \% )}$ \\
Aureobasidium pullulans & 3 \\
Total isolated agents* & 1 \\
* Two patients had polybacterial keratitis, with Pseudomonas spp and Serratia \\
spp isolated in both cases, 25 patients had amebic and bacterial co-infection \\
and 1 case had fungal and bacterial co-infection & \\
\hline
\end{tabular}


The type of lens used was available from patient charts in 109 of the 166 cases of bacterial keratitis. Ninety-six patients were soft-lens wearers $(88.07 \%), 11$ were rigid gas-permeable lens wearers (10.09\%) and 2 used piggy-back lenses (1.83\%). Among the 96 soft-lens wearers, there were 3 cases of therapeutic CL use and 8 cases of cosmetic lens use. Four of the 8 cosmetic CL wearers were using lenses from another person at the time of the infectious event.

In 36 patients with culture-proven bacterial keratitis, inadequate lens hygiene was documented on the charts. Nineteen of them used mostly saline solution while cleaning the lenses and 3 used tap water. Lens wear in the shower was recorded in 15 cases and while swimming in 16 cases. Overnight lens use was noted in 19 of the cases of bacterial keratitis.

Gram-positive bacteria were observed in 110 patients, corresponding to $41.20 \%$ of all the examinations with identified etiological agent and to $66.26 \%$ of all the examinations with a bacterial agent. Gram-negative bacteria were noted in 58 of the cases $(21.72 \%$ of all the examinations with identified etiological agent and $34.94 \%$ of all the examinations showing a bacterial agent).

In the gram-positive group, the most frequent agent was coagulase-negative Staphylococcus (CoNS), which was found in 74 patients $(27.71 \%)$. Corynebacterium spp was present in $20(7.49 \%)$ of the examined cultures.

Pseudomonas spp was the most common gram-negative etiological agent and was isolated in $32(11.98 \%)$ cases. Pseudomonas aeruginosa was the most common species of the genus ( 13 of 32 patients). Serratia spp was isolated in 15 cases and Enterobacter aerogenes in 5 cases. Other gram-negative bacteria found are listed in Table 1. Polybacterial infection was documented in 2 cases, both with association of Pseudomonas spp and Serratia spp.

Coagulase-negative Staphylococcus was susceptible to cephalotin and oxacillin in all 74 cases. No cases of resistance to vancomycin were observed. The second-generation fluoroquinolones ciprofloxacin and ofloxacin were tested in 57 cases, all of them showing susceptibility. Fourth-generation fluoroquinolones were not tested in all cases due to their lack of availability by the time of the examination. Moxifloxacin and gatifloxacin responses were examined in 65 of the 74 cases of CoNS. Resistance was observed in 2 cases: one of them to both moxifloxacin and gatifloxacin and the other only to gatifloxacin. Susceptibility to amikacin, gentamicin and tobramycin was tested in 58, 56 and 52 cases, respectively. No cases of resistance to such aminoglycosides were documented.

In all the 32 cases of Pseudomonas spp, the antibiogram demonstrated susceptibility to ciprofloxacin. Ofloxacin was tested in 29 cases with no cases of resistance. Sensitivity to gatifloxacin was accessed in 23 cases of the cultured Pseudomonas spp and the bacteria showed to be susceptible to this drug in all the tested cases. In regard to aminoglycosides sensitivity, in all of the 32 Pseudomonas cases, the bacteria were sensitive to amikacin and tobramycin. Resistance was observed in one case to gentamicin and in 3 cases to neomycin.
Acanthamoeba was present in $95(39.75 \%)$ patients, of whom $25(26.31 \%)$ had bacterial co-infection. Bacterial agents associated with Acanthamoeba infection are shown in Table 2. In 13 (13.68\%) of the cases of Acanthamoeba keratitis, the patient was taking antiviral drugs, considering the possibility of herpes infection. Data regarding the type of lens used by the patients with amebic keratitis was recorded in 60 cases, among which $52(86.67 \%)$ were soft lenses and 8 $(13.33 \%)$ were rigid gas-permeable lenses. Information on lens care and shower and swimming habits was available in 51 charts. Thirty patients reported inadequate lens hygiene. Twenty-three of them used mainly physiologic saline to clean the lenses and 7 used tap water. Eight patients stated wearing their lenses while showering and 12 while swimming. Only one patient used lenses overnight.

Fungi were noted in $4(1.67 \%)$ of all the cases. In 3 cases, the isolate was a yeast (Candida spp), while in one case it was a filamentous fungus (Aureobasidium pullulans). One of the patients with Candida keratitis had CoNS co-infection.

Culture of CL was performed in 30 cases of laboratoryproven bacterial keratitis and in 13 cases of amebic keratitis. In the 30 cases of bacterial keratitis, the CL culture was positive in 22 examinations, among which 10 (45.45\%) demonstrated growth of the same bacterium as in corneal scraping cultures and $12(54.55 \%)$ did not. In 7 cases, the lens culture was positive for Acanthamoeba, while corneal material showed bacterial growth and provided no evidence of protozoal eye infection. Among the 13 cases of corneal scraping culture-proven Acanthamoeba keratitis, CL culture led to the isolation of the protozoa in 6 cases $(46.15 \%)$ and showed no growth in 7 cases $(53.85 \%)$. Nine $(20.93 \%)$ of the total $43 \mathrm{CL}$ cultures displayed polymicrobial growth.

\section{DISCUSSION}

Several studies have presented consistent data pointing to Pseudomonas as the leading agent in bacterial keratitis in CL users ${ }^{(13,15,28)}$. The results of the present study showed a higher prevalence of CoNS. Coagulase-negative Staphylococcus are among the most frequently isolated bacteria in the clinical microbiology laboratory. Since such bacteria are normal inhabitants of human skin and mucosae, differentiation between clinically significant CoNS and contaminant

\begin{tabular}{|c|c|}
\hline Bacterial agent & $\mathbf{n}$ \\
\hline Coagulase negative Staphylococcus & $20(80 \%)$ \\
\hline Corynebacterium spp * & $3(12 \%)$ \\
\hline Streptococcus viridans & $1(4 \%)$ \\
\hline Serratia spp & $1(4 \%)$ \\
\hline Total & $25(100 \%)$ \\
\hline
\end{tabular}


strains is a challenging task. Considering the meticulous scraping technique followed as a routine in the study, however, the shown high prevalence of CoNS point to CoNS as a main CLMK agent in our environment.

Oxacillin resistance was not found among CoNS in the present study, though increasing prevalence has been observed among general eye infections in Brazil ${ }^{(29-31)}$. Oxacillin resistance is used to evaluate the resistance of Staphylococcus to beta-lactam agents. Resistance to oxacillin and/or methicillin is directly associated with resistance to all betalactam drugs, such as cephalosporins and carbapenems ${ }^{(32)}$. It is thus reasonable to avoid beta-lactam drugs in cases of oxacillin-resistant CoNS, even if they show satisfactory susceptibility to these drugs in vitro.

As for the gram-negative Pseudomonas, resistance to one of the aminoglycoside drugs does not necessarily predict resistance to other drugs of the same class ${ }^{(33)}$. In our study, Pseudomonas resistance to tobramycin and gentamicin was observed in a single case, while no case of amikacin resistance was noted.

Standard empiric therapy for bacterial keratitis has been historically based on the combination of fortified eye drops of cephalosporin and aminoglycoside drugs. In the present study, second-generation fluoroquinolones ciprofloxacin and ofloxacin and fourth-generation fluoroquinolones moxifloxacin and gatifloxacin displayed satisfactory rates of susceptibility to both gram-positive and-negative bacteria. Hyndiluk et al. compared clinical response to ciprofloxacin $0.3 \%$ and tobramycin-cephazolin in cases of bacterial keratitis and found equal results ${ }^{(34)}$. Constantinou et al. also found similar clinical response when comparing moxifloxacin, ofloxacin and fortified tobramycin-cephazolin in the treatment of bacterial keratitis ${ }^{(34)}$. Fluoroquinolones are easily available commercially, since they do not require preparation, and the use of such drugs could be a good choice for initial empiric treatment for CLMK. Considering the higher prevalence of CoNS than Pseudomonas, the use of fourth-generation fluoroquinolones may have a better efficiency than second-generation fluoroquinolones. It is prudent to scrape the cornea before prescribing antibiotics and reconsider treatment options following clinical response and microbiological results.

In this study, there were $95(39.75 \%)$ cases of cultureproven Acanthamoeba keratitis. Previous studies found lower rates of Acanthamoeba infection, with a prevalence ranging from zero to $3.2 \%$ of infectious keratitis from contact lens wear ${ }^{(13,15)}$. This high prevalence can be an indication of unsatisfactory quality of home water system and poor lens care habits. It is also important to consider that the study was conducted in a tertiary Ophthalmology service, which receives more severe cases. Clinical features of Acanthamoeba keratitis is variable and can be mistaken for herpes infection ${ }^{(35)}$. In our data, 13 of the 95 patients $(13.68 \%)$ with positive culture to Acanthamoeba were being treated for herpes keratitis. Owing to the drastic visual loss potentially associated with ameba eye infection and the impact of early diagnosis and treatment, it is essential to consider testing for Acanthamoeba infection even when clinical features point to herpetic etiology, especially considering the lack of consistent data supporting an association between viral infection and CL use.

Fungal infection was found in a minority of the patients $(1.67 \%)$, confirming previous literature findings ${ }^{(7,13,36)}$. In 2006, there was a growing number of reports of Fusarium keratitis that was associated with the use of a specific $\mathrm{ReNu}^{\circledR}$ (Bausch \& Lomb) product with MoistureLoc ${ }^{\mathbb{B}}$ (Bausch \& Lomb). Such association became even more evident after the decline in CL-related Fusarium reports following the recall of the product ${ }^{(25)}$. Other $\mathrm{ReNu}^{\circledR}$ (Baush \& Lomb) products without the MoistureLoc ${ }^{\circledR}$ (Baush \& Lomb) component are commercially available worldwide and also in Brazil, and had not been associated with fungal keratitis.

Despite previous studies supporting a strong association between corneal scrapings and CL cultures ${ }^{(37-38)}$, our results point to a poor agreement. In addition, we found multiple isolates in the CL culture more frequently than in the corneal culture. Such data highlight the notion that the positivity of a CL culture does not always mean corneal infection. The clinical importance of CL culture still remains uncertain, and such information must be pondered with caution for both diagnosis and treatment options.

\section{RESUMO}

Objetivo: A ceratite microbiana associada ao uso de lente de contato é uma condição clínica grave, com risco de perda visual e cuja incidência vem aumentando progressivamente. Os principais agentes etiológicos podem variar geograficamente e informações referentes aos agentes causais são essenciais para tratamento apropriado. Este estudo se propõe a analisar os resultados microbiológicos de raspados de córnea coletados de pacientes usuários de lente de contato com quadro de ceratite microbiana. Métodos: Foi realizada análise retrospectiva de todos os estudos microbiológicos de pacientes usuários de lente de contato com diagnóstico clínico de ceratite microbiana que tiveram material corneal enviado para o Laboratório de Microbiologia Ocular UNIFESP durante o período de 5 anos de janeiro de 2002 a dezembro de 2007. Resultados: Dos 239 pacientes em que foi possível identificação, o agente era bactéria em 166 (69,46\%), Acanthamoeba em 95 (39,75\%) e fungo em 4 (1,67\%). Staphylococcus coagulase negativo foi encontrado em 74 casos, dos quais todos eram sensíveis tanto a ciprofloxacino quanto a ofloxacino. Dois casos de resistência a quinolonas de quarta geração (gatifloxacino e moxifloxacino) foram identificados entre os casos de Staphylococcus coagulase negativo. Pseudomonas spp foi isolada em 32 pacientes, dos quais todos eram sensíveis a quinolonas de segunda geração (ciprofloxacino e ofloxacino) e de quarta geração. Foi encontrado um único caso de Pseudomonas resistente a gentamicina. Conclusão: Staphylococcus coagulase negativo foi isolado em um número de casos superior a Pseudomonas, o 
agente tradicionalmente considerado o principal de ceratites microbianas associadas ao uso de lente de contato. Aminoglicosídeos, fluorquinolonas de segunda e de quarta geração apresentaram um perfil antibiótico satisfatório para o tratamento empírico de ceratites microbianas em usuários de lente de contato.

Descritores: Lentes de contato/efeitos adversos; Ceratite/ microbiologia; Infecções oculares bacterianas; Úlcera de córnea; Acanthamoeba

\section{REFERENCES}

1. Robboy MW, Comstock TL, Kalsow CM. Contact lens-associated corneal infiltrates. Eye Contact Lens. 2003;29(3):146-54.

2. Efron N, Morgan PB. Can subtypes of contact lens-associated corneal infiltrative events be clinically differentiated? Cornea. 2006;25(5):540-4.

3. Miedziak AI, Miller MR, Rapuano CJ, Laibson PR, Cohen EJ. Risk factors in microbial keratitis leading to penetrating keratoplasty. Ophthalmology. 1999;106(6):1166-70; discussion 1171.

4. Bourcier T, Thomas F, Borderie V, Chaumeil C, Laroche L. Bacterial keratitis: predisposing factors, clinical and microbiological review of 300 cases. Br J Ophthalmol. 2003;87(7):834-8.

5. do Sacramento RS, de Castro L, de Freitas D, Branco BC, de Lima AL, Vieira L et al. Estudo dos fatores epidemiológicos e influentes na ceratite microbiana em serviço universitário. Rev Bras Oftalmol. 2005;64(1):7-13.

6. Keay L, Stapleton F, Schein O. Epidemiology of contact lens-related inflammation and microbial keratitis: a 20-year perspective. Eye Contact Lens. 2007;33(6 Pt 2):346-53, discussion 362-3.

7. Seal DV, Kirkness CM, Bennett HG, Peterson M, Keratitis Study Group. Population-based cohort study of microbial keratitis in Scotland: incidence and features. Cont Lens Anterior Eye. 1999;22(2):49-57.

8. Stapleton F, Dart JK, Minassian D. Risk factors with contact lens related suppurative keratitis. CLAO J. 1993;19(4):204-10.

9. Poggio EC, Glynn RJ, Schein OD, Seddon JM, Shannon MJ, Scardino VA et al. The incidence of ulcerative keratitis among users of daily-wear and extended-wear soft contact lenses. N Engl J Med. 1989;321(12):779-83.

10. Stapleton F, Keay L, Edwards K, Naduvilath T, Dart JK, Franzco GB et al The incidence of contact lens-related microbial keratitis in Australia. Ophthalmology. 2008 Jun 4. [Epub ahead of print]

11. Schein OD, Glynn RJ, Poggio EC, Seddon JM, Kenyon KR. The relative risk of keratitis among users of daily-wear and extended-wear soft contact lenses. A case.

15. Stapleton F, Keay LJ, Sanfilippo PG, Katiyar S, Edwards KP, Naduvilath T. Relationship between climate, disease severity, and causative organism for contact lens-associated microbial keratitis in Australia. Am J Ophthalmol. 2007;144(5):690-698.

16. Freitas D. Infecções emergentes em oftalmologia; ceratite por Acanthamoeba [tese]. São Paulo: Universidade Federal de São Paulo; 2000

17. Kashiwabuchi RT, de Freitas D, Alvarenga LS, Vieira L, Contarini P, Sato E, Foronda A, Hofling-Lima AL. Corneal graft survival after therapeutic keratoplasty for Acanthamoeba keratitis.Acta Ophthalmol. 2008 86(6):666-9.

18. Alvarenga LS, de Freitas D, Hofling-Lima AL. Ceratite por Acanthamoeba Arq Bras Oftalmol. 2000; 63(2):155-9.
19. Radford CF, Minassian DC, Dart JK.Acanthamoeba keratitis in England and Wales: incidence, outcome, and risk factors. Br J Ophthalmol. 2002;86(5): 536-42.

20. Radford CF, Bacon AS, Dart JK, Minassian DC. Risk factors for acanthamoeba keratitis in contact lens users: a case-control study. BMJ. 1995;310 (6994):1567-70

21. Nakano E, Oliveira M, Portellinha W, de Freitas D, Nakano K. Confocal microscopy in early diagnosis of Acanthamoeba keratitis. J Refract Surg. 2004;20(5 Suppl):S737-40.

22. Höflin-Lima AL, Roizenblatt R. Therapeutic contact lens-related bilateral fungal keratitis. CLAO J. 2002;28(3):149-50.

23. Chowdhary A, Singh K. Spectrum of fungal keratitis in North India. Cornea. 2005;24(1):8-15.

24. Houang E, Lam D, Fan D, Seal D. Microbial keratitis in Hong Kong: relationship to climate, environment and contact-lens disinfection.Trans $\mathrm{R}$ Soc Trop Med Hyg. 2001;95(4):361-7.

25. Levy B. Risk factors for contact lens related fusarium keratitis. Arch Ophthalmol. 2007;125(12):1715-6; author reply 1716 .

26. Levy B, Heiler D, Norton S. Report on testing from an investigation of fusarium keratitis in contact lens wearers. Eye Contact Lens. 2006;32(6):256-61.

27. Tuli SS, Iyer SA, Driebe WT Jr. Fungal keratitis and contact lenses: an old enemy unrecognized or a new nemesis on the block? Eye Contact Lens. 2007; 33(6 Pt 2):415-7; discussion 424-5.

28. Leite Neto AQ, Tavares AD, Costa HJ, Florêncio AC, Sales C. Estudo microbiológico em lentes de contato. Rev Bras Oftalmol. 2001;60(5):370-3.

29. Oliveira AD, Höfling-Lima AL, Belfort R Jr, Gayoso Mde F, Francisco W. Fluoroquinolone susceptibilities to methicillin-resistant and susceptible coagulase-negative Staphylococcus isolated from eye infection. Arq Bras Oftalmol. 2007;70(2):286-9.

30. Oliveira AD, D'Azevedo PA, Francisco W. In vitro activity of fluoroquinolones against ocular bacterial isolates in São Paulo, Brazil. Cornea. 2007;26 (2):194-8.

31. Hofling-Lima AL, Belfort Jr R, Moeller CTA, Branco BC, Sousa LB, Freitas D. In vitro antibiotic susceptibilities of ocular bacteria isolates from the cornea and conjunctiva to moxifloxacin, gatifloxacin and other fluorquinolones [abstract]. Arq Bras Oftalmol. 2004;67(6):3.

32. Centers for Disease Control and Prevention. Laboratory detection of oxacillinresitant coagulase-negative staphylococcus spp [Internet]. Atlanta (GA): CDC; 1999 [cited 2008 Mar 25]. Available from: http://www.cdc.gov/ncidod/dhqp/ ar_lab_oxa.html.

33. Centers for Disease Control and Prevention. Aminoglycoside resistance in enterobacteriaceae and pseudomonas aeruginosa [Internet]. Atlanta (GA): CDC; 1999 [cited 2008 Mar 25].1999. Available from: http://www.cdc.gov/ncidod/ dhqp/ar_lab_amino.html.

34. Hyndiuk RA, Eiferman RA, Caldwell DR, Rosenwasser GO, Santos CI, Katz $\mathrm{HR}$ et al. Comparison of ciprofloxacin ophthalmic solution $0.3 \%$ to fortified tobramycin-cefazolin in treating bacterial corneal ulcers. Ciprofloxacin Bacterial Keratitis Study Group. Ophthalmology. 1996;103(11):1854-62; discussion 1862-3.

35. Alvarenga LS Freitas D. Ceratite dendritiforme em usuários de lentes de contato. Arq Bras Oftalmol. 2003; 66(4):539-93.

36. de Andrade AJ, Vieira LA, Hofling-Lima AL, Yu MC, Gompertz OF, de Freitas D, de Souza LB. Laboratorial analysis of fungal keratitis in a university service. Arq Bras Oftalmol [Internet]. $2000 \mathrm{Fev}$ [cited 2008 Ago 20]; 63(1):59-63. Available from: http://www.scielo.br/pdf/abo/v63n1/13607.pdf.

37. Martins EN, Farah ME, Alvarenga LS, Yu MC, Höflin-Lima AL. Infectious keratitis: correlation between corneal and contact lens cultures. CLAO J. 2002;28(3):146-8

38. Das S, Sheorey H, Taylor HR, Vajpayee RB. Association between cultures of contact lens and corneal scraping in contact lens related microbial keratitis. Arch Ophthalmol. 2007;125(9):1182-5. 